\title{
STUDI ANALISIS KUALITAS AIR SUNGAI CIBANTEN KABUPATEN SERANG PROVINSI BANTEN
}

\author{
Yonik Meilawati Yustiani ${ }^{*}$, Sri Wahyuni, Alexander Saputra \\ Program Studi Teknik Lingkungan, Universitas Pasundan
}

\begin{abstract}
Abstrak
Sungai Cibanten merupakan salah satu DAS (Daerah Aliran Sungai) yang memiliki nilai penting bagi Kabupaten Serang dan sekitarnya. Saat ini telah terjadi kerusakan lingkungan di Sungai Cibanten, ini dibuktikan dari hasil pengamatan yang dilakukan oleh Dinas lingkungan Hidup Kabupaten Serang, dimana beberapa parameternya melebihi baku mutu yang ditetapkan. Sumber pencemar di Sungai Cibanten yang paling dominan berasal dari limbah penduduk. Untuk itu perlu dilakukan upaya pengelolaan kualitas air Sungai Cibanten agar kualitas airnya tetap terjaga. Pemeriksaan kualitas air sungai dilakukan di 6 (enam) titik pengamatan berdasarkan pertimbangan tingginya potensi pencemar dan banyaknya sumber pencemar. Penentuan titik pengamatan ini juga berdasarkan dari data sekunder yang pernah dilakukan oleh Dinas Lingkungan Hidup Kabupaten Serang, dimana titik pengamatan dimulai dari hulu (Desa Pancanegara) sampai hilir (Desa Margaluyu) yang merupakan muara Sungai Cibanten. Metode pemeriksaan parameter-parameter tersebut disesuaikan dengan Standard Methods for Examination of Water and Wastewater. Dari hasil pemeriksaan sampel air pada bulan Maret 2008, memperlihatkan bahwa sebagian parameter fisika-kimia air masih memenuhi standar baku mutu yang diperbolehkan untuk standar buangan sungai/ stream standar berdasarkan Peraturan Pemarintah RI No.82 Tahun 2001, kecuali untuk sebagian parameter kimia ada 5 (lima) parameter yang nilainya tidak memenuhi standar baku mutu yang ditetapkan, antaralain parameter BOD, COD, DO, Zat organik dan Ammunium.
\end{abstract}

Kata kunci: kualitas air, parameter fisika-kimia, pencemaran

\section{Pendahuluan}

Pencemaran air Sungai Cibanten terjadi akibat berbagai sumber pencemar yang dapat berupa buangan rumah tangga, pertanian, peternakan, industri atau jenis buangan lain yang berasal dari penggunaan badan air secara langsung, seperti: MCK, transportasi air, dan lain sebagainya. Akibatnya kualitas air dapat menurun sehingga tidak lagi memenuhi persyaratan kualitas

\footnotetext{
${ }^{*}$ Penulis Korespondensi:

E-mail: yonik@unpas.ac.id

Diterima pertama kali: 11 November 2017

Direvisi : 5 Januari 2018

Disetujui untuk publikasi: 12 Februari 2018
}

peruntukan yang telah ditetapkan (Baherem, Suprihatin, \& Indrasti, 2014). Air yang tercemar di samping dapat mengganggu pertumbuhan dan perkembangan organisme akuatik, juga dapat mengganggu kesehatan masyarakat, karena dapat menimbulkan penyakit bawaan air seperti disentri, gangguan estetika lingkungan seperti menimbulkan bau dan juga tidak sedap dipandang (Yustiani \& Komariah, 2017). Kondisi ini dikarenakan Sungai Cibanten mengalir melewati perkotaan, dengan demikian kondisi Sungai Cibanten saat ini kondisinya menjadi menurun. Hal ini dapat dilihat dari hasil pengamatan yang dilakukan oleh Dinas Pengelolaan Lingkungan Hidup Kabupaten 
Serang Provinsi Banten, yang beberapa parameternya melebihi kualitas baku mutu yang telah ditetapkan.

Pemantauan dan evaluasi terhadap kualitas air yang sekarang ini dilakukan oleh Dinas Pengelolaan Lingkungan Hidup Kabupaten Serang mengacu pada baku mutu perairan menurut Peraturan Pemerintah RI No. 82 Tahun 2001 golongan I yang merupakan peruntukkan sebagai air baku air minum, dan atau peruntukkan lain yang mempersyaratkan mutu air yang sama dengan kegunaan tersebut. Dipilihnya Sungai Cibanten sebagai lokasi Studi Kualitas Air, dikarenakan Sungai ini merupakan sumber kebutuhan bagi masyarakat, di samping itu sungai ini mengalir melintasi daerah perkotaan yang merupakan tempat pembuangan limbah domestik, rumah sakit, peternakan dan pertanian. Sehingga berpotensi menimbulkan pencemaran air yang akhirnya dapat mengganggu segi estetika dan mengancam kesehatan lingkungan.

Adapun tujuan dari penelitian ini adalah untuk mengetahui kualitas air Sungai Cibanten dan untuk mengetahui tingkat pencemaran di sekitar Sungai Cibanten, agar dapat ditarik kesimpulan dan diberikan usulan penanggulangannya.

\section{Metodologi \\ Lokasi}

Pengambilan sampel dilakukan pada saat musim hujan. Lokasi penelitian ini dilakukan di wilayah Kabupaten Serang Banten. Penentuan lokasi pengambilan sampel air sungai ditentukan dengan mempertimbangkan tingginya potensi pencemaran dan banyaknya sumber pencemaran. Selain itu yang menjadi pertimbangan adalah kemudahan pengambilan sampel baik secara teknis, maupun non teknis (waktu dan biaya). Agar dapat dibandingkan dan dianalisis kecenderungan kualitas air Sungai Cibanten, maka pemilihan lokasi pengambilan sampel dilakukan berdasarkan pada data sekunder yang telah ada, yang diambil dari Dinas Pengelolaan Lingkungan Hidup Kabupaten Serang dan dibeberapa titik yang dianggap dapat mewakili kondisi yang ada. Tabel 1 merupakan daftar lokasi pengambilan sampel. Titik nomor 1 ditetapkan sebagai titik kilometer 0 untuk keperluan perhitungan dalam penelitian ini.

Tabel 1. Lokasi Pengambilan Sampel di Sungai Cibanten

\begin{tabular}{ccc}
\hline No. & $\begin{array}{c}\text { Jarak Titik } \\
\text { Pengambilan } \\
\text { Sampel terhadap } \\
\text { titik nomor 1 } \\
(\mathbf{K m})\end{array}$ & $\begin{array}{c}\text { Lokasi } \\
\text { pengambilan } \\
\text { Sampel }\end{array}$ \\
\hline 1 & 0 & Desa Pancanegara \\
\hline 2 & 8.8 & Kelurahan Gelam \\
\hline 3 & 14.17 & $\begin{array}{c}\text { Upstream Rumah } \\
\text { Sakit }\end{array}$ \\
\hline 4 & 14.91 & $\begin{array}{c}\text { Downstream } \\
\text { Rumah Sakit }\end{array}$ \\
\hline 5 & 21.63 & Kelurahan Unyur \\
\hline 6 & 29.54 & Desa Margaluyu \\
\hline
\end{tabular}

\section{Pengumpulan Data}

Pengumpulan data pada penelitian ini meliputi data primer dan data sekunder. Data primer dilakukan dengan pengambilan sampel air dan analisa di laboratorium, sedangkan data sekunder digunakan sebagai data pendukung. Data sekunder ini didapatkan dari instansi terkait yang menangani pengelolaan kualitas air sungai khususnya untuk DAS Cibanten. Pengambilan contoh air dilakukan secara sampel sesaat (grab sampling). Parameter fisik yang juga diuji, meliputi ; suhu, kekeruhan dan warna. Sedangkan parameter kimia yang diuji meliputi $\mathrm{pH}, \mathrm{BOD}, \mathrm{COD}, \mathrm{DO}$, nitrat, nitrit, ammonium dan zat organik. Pengambilan sampel kualitas air mengacu pada Standard Method. Dalam Standard Method ini dijelaskan tata cara pengambilan sampel, wadah sampel yang digunakan dan cara mengawetkan sampel.

Mengumpulkan data-data penunjang berkaitan dengan penelitian yang dilakukan serta mencari informasi dari berbagai instansi, seperti DPLH, 
Badan Pengelolaan Sumber Daya Air (BPSDA) dan BAPPEDA Kabupaten Serang.

Pemeriksaan dan pengukuran contoh air sungai di lapangan dilakukan terutama untuk memeriksa dan mengukur parameter yang mudah seperti, suhu, keasaman $\mathrm{pH}$, DO dan debit. Metode pemeriksaan di lapangan ini, dilakukan berdasarkan Standard Method.

\section{Analisis Data Kualitas Air}

Analisis data merupakan serangkaian pekerjaan menganalisis data yang telah dikumpulkan dari data sekunder yaitu data hasil pemeriksaan kualitas air yang dilakukan oleh DLH Kabupaten Serang dan data primer yaitu data yang didapat dari pengukuran kualitas air yang dilakukan langsung di lapangan dan di laboratorium oleh peneliti, serta pengamatan kondisi lahan di lapangan.

Berdasarkan hasil data penelitian, maka data yang telah terkumpul digunakan untuk mengidentifikasi tingkat pencemaran serta dampak yang akan diakibatkan dari berbagai aktivitas yang dilakukan oleh penduduk terhadap kondisi Sungai Cibanten. Data primer yang telah diperoleh dari hasil penelitian di lapangan dibandingkan dengan standar baku mutu air sungai yang digunakan sesuai dengan Peraturan Pemerintah N0. 82 Tahun 2001 tentang pengelolaan kualitas air dan pencemaran air (stream standard) dalam bentuk tabel, sehingga diketahui apakah dari beberapa parameter yang diperiksa melebihi standar baku mutu yang telah ditetapkan atau tidak. Kemudian dibuat grafik yang menunjukkan tingkat pencemaran dari beberapa parameter yang diperiksa terhadap jarak titik pengambilan sampel, dengan tujuan memperlihatkan apakah pada titik-titik pengambilan sampel air tersebut terjadi peningkatan atau penurunan nilai pencemaran.

\section{Hasil dan Pembahasan}

Pemeriksaan sampel air sungai dilakukan di laboratorium air Teknik Lingkungan Institut Teknologi Bandung. Hasil penelitian ini dibandingkan dengan standar baku mutu berdasarkan Peraturan Pemerintah RI No.82 Tahun 2001 golongan I.

Untuk data primer, lokasi pengambilan sampel yang dilakukan terdiri dari 6 (enam) titik, dimana masing-masing titik terdapat beberapa sumber pencemar.

Tabel 2. Hasil Pengukuran Kualitas Air Sungai

\begin{tabular}{|c|c|c|c|c|c|c|c|c|c|}
\hline \multirow[b]{2}{*}{ No } & \multirow[b]{2}{*}{ Parameter } & \multirow[b]{2}{*}{ Satuan } & \multirow{2}{*}{$\begin{array}{l}\text { Baku } \\
\text { Mutu }\end{array}$} & \multicolumn{6}{|c|}{ Lokasi Pengambilan Sampel } \\
\hline & & & & titik 1 & titik 2 & titik 3 & titik 4 & titik 5 & titik 6 \\
\hline \multicolumn{10}{|c|}{ FISIKA } \\
\hline 1 & Suhu & ${ }^{\circ} \mathrm{C}$ & $27-32,5$ & 27,1 & 28,2 & 27,5 & 28,2 & 27 & 28,6 \\
\hline 2 & $\mathrm{Bau}$ & - & . & $\begin{array}{r}\text { Tidak } \\
\text { berbau }\end{array}$ & $\begin{array}{l}\text { Tidak } \\
\text { berbau }\end{array}$ & $\begin{array}{c}\text { Tidak } \\
\text { berbau }\end{array}$ & berbau & $\begin{array}{c}\text { Tidak } \\
\text { berbau }\end{array}$ & berbau \\
\hline & & Unit & & 25 & 20 & 25 & 25 & 30 & 40 \\
\hline 3 & Warna & Pt-Co & 50 & koloid & koloid & koloid & koloid & koloid & koloid \\
\hline 4 & Kekeruhan & NTU & 25 & 154 & 147 & 139,5 & 169 & 212 & 338 \\
\hline \multicolumn{10}{|c|}{ KIMIA } \\
\hline 1 & $\mathrm{pH}$ & - & 6-9 & 7,62 & 7,46 & 8,67 & 9,86 & 7,82 & 8,75 \\
\hline 2 & Zat Organik & $\mathrm{mg} / \mathrm{L}$ & 10 & 9,45 & 22,75 & 22,095 & 31,005 & 33,965 & 39,95 \\
\hline 3 & BOD & $\mathrm{mg} / \mathrm{L}$ & 2 & 15 & 17,5 & 15 & 13 & 14 & 15 \\
\hline 4 & COD & $\mathrm{mg} / \mathrm{L}$ & 10 & 23,08 & 22,6 & 20,195 & 29,81 & 25 & 26,445 \\
\hline 5 & DO & $\mathrm{mg} / \mathrm{L}$ & 6 & 2,364 & 3,159 & 2,852 & 2,124 & 3,21 & 2,821 \\
\hline 6 & Nitrit & $\mathrm{mg} / \mathrm{L}$ & 0,06 & 0,244 & 0,014 & 0,0105 & 0,02 & 0,016 & 0,012 \\
\hline 7 & Nitrat & $\mathrm{mg} / \mathrm{L}$ & 10 & 3,295 & 4,76 & 4,385 & 4,52 & 4,465 & 4,1 \\
\hline 8 & Ammonium & $\mathrm{mg} / \mathrm{L}$ & 0,02 & 0,005 & 0,143 & 0,075 & 0,292 & 0,267 & $\mathbf{0 , 3 6 3}$ \\
\hline
\end{tabular}




\section{Parameter Fisika}

Pada titik 1,2,3,5 air sungai tidak berbau, dimana pada titik 1 hanya terdapat lokasi pertanian tanaman tahunan dan pertanian lahan kering. pada titik 2,3 dan 5 merupakan lokasi perumahan penduduk dimana sebagian besar limbah yang dibuang berupa sampah plastik dan padatan. Hal ini berbeda dengan titik 4 dan 6 , dimana pada titik 4 merupakan lokasi pembuangan limbah dari aktivitas Rumah Sakit Umum Kabupaten Serang yang berbau kurang sedap. Sedangkan pada titik 6 merupakan lokasi yang dekat dengan tempat pelelangan ikan, tempat aktivitas bongkar muat kapal dan dekat dengan tambak ikan serta adanya buangan dari rumah tangga, sehingga menyebabkan bau pada lokasi titik 6. Untuk parameter warna, pada tiap titik pengambilan sampel tidak melebihi batas baku mutu yang ditetapkan. Sedangkan bila dilihat dari kekeruhannya semua lokasi titik pengambilan sampel melebihi batas baku mutu Peraturan Pemerintah RI No.82 Tahun 2001. Gambar 10, 11 dan 12 memperlihatkan Tingkat pencemaran dengan parameter fisika untuk kualitas Air Sungai Cibanten.

Mulai dari titik 1 sampai titik 6 mula-mula nilai suhu sebesar $27,1^{\circ} \mathrm{C}$ kemudian pada titik 2 nilai suhu meningkat menjadi $28,2^{\circ} \mathrm{C}$ namun pada titik 3 terjadi penurunan dengan nilai suhu sebesar $27,5^{\circ} \mathrm{C}$ dan pada titik 4 suhu kembali naik dan memiliki nilai yang sama seperti pada titik 2 yakni $28,2{ }^{\circ} \mathrm{C}$. Kemudian pada titik 5 nilainya kembali menurun sedikit di bawah suhu pada titik awal yakni sebesar $27{ }^{\circ} \mathrm{C}$ dan pada titik 6 suhu meningkat dengan nilai $28,6^{\circ} \mathrm{C}$. Tinggi rendahnya suhu berkaitan dengan interaksi udara dan air, bila udara panas dan banyaknya air panas yang dibuang ke sungai maka akan menyebabkan suhu menjadi naik. Variasi dari parameter suhu air yang diperlihatkan tidak menunjukkan perbedaan yang besar. Hal ini menunjukkan bahwa semua titik pengamatan tersebut berada dalam suatu kawasan dengan pengaruh yang relatif sama terhadap suhu air normal.

Kualitas warna dimulai dari titik 1 ke titik 2 terjadi penurunan dan pada titik 3 dan 4 nilai warna kembali naik dengan nilai yang sama seperti pada titik 1 yakni sebesar 25 unit Pt-Co. Kemudian nilai warna terus meningkat pada titik 5 sampai ke titik 6 dan terlihat bahwa nilai yang didapat semuanya masih memenuhi nilai baku mutu yang ditetapkan berdasarkan Peraturan Pemerintah RI No.82 Tahun 2001 unit Pt-Co. Hal ini diduga dapat terjadi karena limbah yang terbawa akan tercampur dengan air sungai, dikarenakan pada bulan itu sering turun hujan sehingga terjadi proses pengenceran.

Nilai yang didapat dari ke enam titik pengambilan sampel semuanya melebihi nilai ambang baku kualitas air berdasarkan Peraturan Pemerintah RI No.82 Tahun 2001. Dimana batas nilai yang diperbolehkan adalah 25 NTU. Pada titik 1 kekeruhan sebesar 154 NTU, lalu menurun pada titik 2 dengan nilai 147 NTU dan kembali menurun di titik 3 sebesar 139,3 NTU. Hal ini dikarenakan kemungkinan terjadinya penguraian selama perjalanan dari titik 1 menuju titik 2 dan 3. Lalu terjadi kenaikan pada titik 4 sampai dengan titik 5 dan 6 dengan nilai sebesar 338 NTU. Besarnya nilai kekeruhan disebabkan oleh banyaknya limbah yang dibuang ke sungai dari berbagai aktivitas penduduk yang dapat menyebabkan bertambah banyaknya bahanbahan organik yang terlarut dalam air dan terbawa aliran sampai ke muara sungai. Selain itu terdapat juga kegiatan penambangan pasir yang dilakukan berdekatan dengan beberapa titik pengambilan sampel, sehingga menyebabkan nilai kekeruhan air sungai menjadi tinggi.

\section{Parameter Kimia}

Pengukuran $\mathrm{pH}$ dilakukan langsung di lapangan dimana nilai $\mathrm{pH}$ pada titik 1 adalah 7,62, pada titik 2 sebesar 7,46 pada titik 3 sebesar 8,67 pada titik 4 adalah 9,86 dan pada titik 5 adalah 7,82 sedangkan pada titik 6 nilai $\mathrm{pH}$ sebesar 8,75. 
Pada lokasi pengambilan sampel titik 1,2,3,5 dan 6 nilainya masih memenuhi standar baku mutu, dimana standar yang diperbolehkan adalah antara 6 sampai 9. Hal ini berbeda pada titik 4, dimana nilainya melebihi standar baku mutu dan konsentrasinya mendekati basa.

Tingkat keasaman $(\mathrm{pH})$ pada air di titik 1 adalah sebesar 7,62, dimana pada titik ini hanya terdapat pertanian lahan kering dan diduga terjadi penguraian dalam menempuh perjalanan menuju titik 2 dengan nilai 7,46 sehingga terjadi penurunan di titik 2 dimana pada titik ini hanya terdapat permukiman penduduk, dan pada saat dilakukannya pengambilan sampel air aktivitas yang ada di sungai tersebut terlihat sepi. Selanjutnya pada titik 3 mengalami kenaikan dengan nilai 8,67 tetapi di ketiga titik ini masih berada dalam batas normal, kemudian nilai $\mathrm{pH}$ meningkat pada titik 4 sebesar 9,86 dan melebihi baku mutu, dimana lokasi ini merupakan Down Stream RS dan diduga adanya masukan limbah yang dihasilkan dari kegiatan Rumah Sakit Umum Kabupaten Serang tersebut. Pada titik 5 nilai $\mathrm{pH}$ sebesar 7,82 dan kembali menurun, pada titik ini teridentifikasi adanya buangan yang dihasilkan dari kegiatan domestik saja dan tak jauh dari permukiman penduduk terdapat dua instalasi pengolahan air minum yang sumber air bakunya diambil dari Sungai Cibanten. Selanjutnya pada titik 6 nilai $\mathrm{pH}$ sebesar 8,75 kembali mengalami kenaikan, pengambilan sampel pada titik ini merupakan lokasi dekat muara Sungai Cibanten dimana banyak sekali aktivitas yang dilakukan oleh penduduk seperti bongkar muat kapal dan dekat dengan tempat pelelangan ikan, tetapi berdasarkan hasil pengukuran di lapangan nilai keasaman/ $\mathrm{pH}$ pada titik ini masih memenuhi baku mutu yang telah ditetapkan.

Berdasarkan hasil penelitian di laboratorium nilai zat organik untuk air sungai pada titik 1 adalah 9,45, titik 2 adalah 22,75, titik 3 adalah
22,095, pada titik 4 adalah 31,005 dan pada titik 5 adalah 33,965 serta pada titik 6 adalah 39,95.

Tingkat pencemaran untuk zat organik pada kualitas air bervariasi. Pada titik 1 nilai konsentrasi organik air rendah, pada titik 2 nilai konsentrasi organiknya tinggi, dikarenakan pada lokasi tersebut limbah yang dihasilkannya berasal dari permukiman penduduk serta fasilitas lainnya seperti hotel, rumah makan dan fasilitas lain yang membuang limbahnya ke sungai dan juga adanya masukan buangan dari bagian hulunya. Pada titik 3 nilai konsentrasi organik pada air sedikit menurun, penurunan konsentrasi zat organik pada titik 3 ini karena adanya masukan dari titik sebelumnya (titik 2) hanya sedikit dan senyawa organik pada titik 3 dihasilkan dari limbah domestik. Pada titik 4 nilai konsentrasi organik air kembali naik, karena di lokasi tersebut merupakan tempat pembuangan limbah rumah sakit dan adanya masukan limbah dari titik sampling sebelumnya dan juga aliran airnya cukup deras yang menyebabkan konsentrasi pencemarnya meningkat. Pada titik 5 konsentrasi kembali naik sampai dengan di titik 6 . Tingginya konsentrasi organik pada titik ini kemungkinan disebabkan karena adanya masukan limbah yang berasal dari banyak kegiatan antara lain kegiatan rumah tangga berupa kotoran manusia dan sampah organik dari hasil kegiatan dapur dan adanya kegiatan bongkar muat kapal yang dilakukan oleh nelayan serta adanya masukan pencemaran dari kegiatan tambak ikan dan udang yang ada di sekitar muara Sungai Cibanten.

Berdasarkan hasil pengukuran, konsentrasi BOD merupakan salah satu parameter yang paling banyak mencemari Sungai Cibanten. Nilai BOD untuk titik 1 adalah $15 \mathrm{mg} / \mathrm{L}$, titik 2 adalah 17,5 $\mathrm{mg} / \mathrm{L}$, titik 3 adalah $15 \mathrm{mg} / \mathrm{L}$, titik 4 adalah 13 $\mathrm{mg} / \mathrm{L}$, titik 5 adalah $14 \mathrm{mg} / \mathrm{L}$ dan titik 6 adalah $15 \mathrm{mg} / \mathrm{L}$. Pada kualitas air nilai BOD mengalami peningkatan pada titik 1 menuju titik 2 , kemudian nilainya kembali turun sama seperti di 
titik 1 yakni sebesar $15 \mathrm{mg} / \mathrm{L}$. Pada titik 4 terjadi penurunan kembali nilai BOD kemudian perlahan naik konsentrasinya pada titik 5 lalu nilainya kembali naik di titik 6 sama seperti pada titik 1 dan 3 yakni sebesar $15 \mathrm{mg} / \mathrm{L}$. Tingginya BOD di Sungai Cibanten disebabkan karena banyaknya limbah yang dibuang ke sungai, baik limbah yang bersifat cair maupun padat. Pada titik 1 limbah yang masuk ke sungai banyak dihasilhan dari aktivitas petani pada lahan pertanian, pada titik 2 dan 3 masukan limbahnya berasal dari permukiman penduduk dan babarapa fasilitas lainnya, pada titik 4 masukan limbahnya berasal dari rumah sakit dan adanya masukan dari titik sebelumnya, pada titik 5 pencemarnya barasal dari kegiatan rumah tangga dan adanya pembuangan lumpur yang dihasilkan dari instalasi pengolahan air minum dan pada titik 6 adanya masukan limbah dari aktivitas pelelangan ikan dan adanya masukan dari titik sebelumnya. BOD yang tinggi menunjukkan banyaknya bahan organik yang masuk ke dalam Sungai Cibanten dan terlihat bahwa nilai BOD pada semua titik pengambilan sampel melebihi baku mutu yang telah ditetapkan.

Berdasarkan hasil pemeriksaan di laboratorium, nilai COD dalam air sungai pada titik 1 sebesar 23,08 mg/L, pada titik 2 sebesar 22,6 mg/L, pada titik 3 sebesar 20,195 mg/L, pada titik 4 sebesar 29,81 mg/L, pada titik 5 sebesar 25 $\mathrm{mg} / \mathrm{L}$ dan pada titik 6 nilai COD sebesar 26,445.

Terjadi penurunan nilai COD pada titik 1 menuju titik 2 dan 3 dan terjadi kenaikan pada titik 4, dikarenakan pada titik 4 adanya masukan pencemar dari aktivitas Rumah Sakit dan nilai COD kembali menurun pada titik 5 kemudian mengalami kenaikan kembali pada titik 6 yang merupakan lokasi yang dekat dengan pelelangan ikan, bongkar muat kapal, pasar tradisional dan dekat dengan lokasi tambak nelayan. Standar baku mutu yang ditetapkan adalah $10 \mathrm{mg} / \mathrm{L}$, sehingga nilai COD pada semua titik pengambilan sampel melebihi batas baku mutu berdasarkan PP RI No.82 Tahun 2001 golongan I.

Nilai konsentrasi DO pada titik 1 mengalami kenaikan di titik 2 dan konsentrasi DO kembali menurun di titik 3 dan 4, oksigen terlarut mengalami peningkatan pada titik 5 dan sedikit menurun kembali di titik 6. Dari hasil pengukuran yang dilakukan di lapangan nilai oksigen terlarut dalam air sungai untuk titik 1 sebesar 2,364 mg/L, titik 2 sebesar 3,159 mg/L, titik 3 sebesar $2,852 \mathrm{mg} / \mathrm{L}$, titik 4 sebesar 2,124 $\mathrm{mg} / \mathrm{L}$, untuk titik 5 sebesar $3,21 \mathrm{mg} / \mathrm{L}$ dan pada titik 6 nilai DO nya sebesar 2,821 mg/L. Bila dilihat dari standar baku mutu untuk air adalah 6 $\mathrm{mg} / \mathrm{L}$, maka dari ke enam titik lokasi pengambilan sampel semua nilainya tidak memenuhi standar baku mutu yang di perbolehkan. Penurunan oksigen terlarut di sungai kemungkinan disebabkan oleh adanya peningkatan jumlah mikroorganisme yang menguraikan zat organik yang terdapat pada air.

Berdasarkan hasil penelitian di laboratorium kandungan nitrit dalam air sungai pada titik 1 sebesar 0,244 mg/L, titik 2 sebesar 0,014 mg/L, untuk titik 3 sebesar $0,0105 \mathrm{mg} / \mathrm{L}$, titik 4 sebesar $0,02 \mathrm{mg} / \mathrm{L}$, titik 5 sebesar $0,016 \mathrm{mg} / \mathrm{L}$ dan titik 6 sebesar 0,012 mg/L. Berdasarkan standar baku mutu maksimum yang diperbolehkan adalah sebesar $0.06 \mathrm{mg} / \mathrm{L}$, ini berarti bahwa kandungan nitrit yang berada pada titik 1 tidak memenuhi baku mutu, sedangkan pada titik pengamatan 2,3,4,5 dan 6 masih memenuhi standar baku mutu yang diperbolehkan. Pada gambar terlihat bahwa konsentrasi nitrit di titik 1 lebih besar dari pada titik-titik di hilirnya, kemungkinan ini disebabkan karena pada lokasi ini merupakan lahan pertanian dan adanya peternakan hewan yang dilakukan oleh masyarakat di sekitar Desa Pancanegara dan masyarakat yang tinggal dipinggiran Sungai Cibanten. Dimana limbah dari aktivitas pertanian dan peternakan yang ada langsung dibuang ke sungai. 
Kandungan nitrat pada air sungai dari hasil penelitian yang dilakukan di laboratorium pada titik 1 adalah 3,295 $\mathrm{mg} / \mathrm{L}$, titik 2 sebesar 4,76 $\mathrm{mg} / \mathrm{L}$, untuk titik 3 sebesar $4,385 \mathrm{mg} / \mathrm{L}$, titik 4 sebesar 4,52 mg/L, titik 5 sebesar 4,465 mg/L dan pada titik 6 sebesar 4,1mg/L, dengan standar baku mutu yang diperbolehkan sebesar $10 \mathrm{mg} / \mathrm{L}$. Berarti kadar nitrat dalam air sungai tersebut masih memenuhi standar baku mutu. Pada gambar terlihat bahwa kandungan nitrat tertinggi pada air terdapat pada titik 2. Kandungan nitrat $<0,226 \mathrm{mg} / \mathrm{L}$ mengindikasikan suatu perairan kurang subur (Amin, 2015). Nilai nitrat di Sungai Cibanten ini masih bersifat normal dan tidak menimbulkan pencemaran terhadap sungai tersebut. Ketidakstabilan nitrat dalam air dikarenakan adanya proses denitrifikasi di dalam perairan.

Nilai konsentrasi ammonium pada air mulai dari titik 1 sampai titik 6 mengalami peningkatan. Kandungan ammonium ini cukup dominan berada dalam perairan dibandingkan unsur hara lainnya. Dalam batas-batas tertentu konsentrasi ammonium dapat berakibat negatif terhadap kehidupan biota dalam perairan sekitarnya sebagai akibat dari racun yang ditimbulkan dari ammonia tersebut. Ammonium dalam perairan terdapat dalam bentuk ion ammonium $\left(\mathrm{NH}_{4}{ }^{+}\right)$ dan gas ammonia, proses tersebut dinamakan proses ammonifikasi, yaitu proses perubahan nitrogen organik menjadi ammonia. Proses ini dapat dilakukan oleh tumbuh-tumbuhan, hewan dan mikroorganisme lainnya. Tanaman dan hewan yang mati akan diuraikan oleh mikroorganisme menjadi ammoniak. Ammoniak yang tinggi juga disebabkan proses nitrifikasi tidak terjadi karena oksigen terlarut yang rendah dan juga oksigennya banyak terpakai oleh penguraian senyawa organik.

Kandungan ammonium dalam air sungai dari hasil penelitian di laboratorium untuk titik 1 sebesar 0,005 mg/L, titik 2 sebesar 0,143 mg/L, titik 3 sebesar $0,075 \mathrm{mg} / \mathrm{L}$, titik 4 sebesar 0,292 $\mathrm{mg} / \mathrm{L}$, titik 5 sebesar $0,267 \mathrm{mg} / \mathrm{L}$ dan untuk titik 6 sebesar $0,363 \mathrm{mg} / \mathrm{L}$.

\section{Kesimpulan}

Berdasarkan hasil penelitian, maka dapat disimpulkan bahwa :

1. Pada lokasi penelitian, sungai Cibanten mengalir melewati daerah perkotaan, sehingga pencemaran yang terjadi banyak ditimbulkan dari aktivitas penduduk yang ada di sekitar sungai.

2. Hasil penelitian menunjukkan bahwa hampir semua parameter kimia melebihi baku mutu yang telah ditetapkan berdasarkan Peraturan Pemerintah RI No.82 Tahun 2001 golongan I tentang peruntukkan air untuk air baku air minum, dan atau peruntukkan lain yang mempersyaratkan mutu air yang sama dengan kegunaan tersebut. Kecuali untuk parameter nitrat yang masih memenuhi baku mutu. Hal ini menunjukkan bahwa pencemaran yang terjadi di sungai Cibanten sudah cukup parah.

3. Dari hasil pengukuran baik yang dilakukan di lapangan maupun di laboratorium, parameter yang tidak memenuhi baku mutu dari semua titik pengambilan sampel antara lain parameter BOD, COD, DO, Zat organik dan Ammonium. Untuk parameter BOD, dari hasil pengukuran didapatkan nilai konsentrasi terbesar terdapat pada titik 2 yakni sebesar 17,5 mg/L. Bila dilihat hasil pengukuran, nilai parameter COD terbesar terdapat pada titik pengambilan sampel ke 4 yakni sebesar $29,81 \mathrm{mg} / \mathrm{L}$. Untuk parameter DO, nilai konsentrasi DO terkecil yang terdapat pada titik pengambilan sampel ke 4 yakni sebesar 2,124 mg/L. Untuk parameter zat organik, nilai konsentrasi terbesar terdapat pada titik pengambilan sampel ke 6 yakni sebesar 39,95 mg/L Sedangkan untuk parameter Ammonium, nilai konsentrasi 
terbesar terdapat pada titik pengambilan sampel ke 6 yakni sebesar $0,363 \mathrm{mg} / \mathrm{L}$

\section{Daftar Pustaka}

Amin, M. (2015). Studi Kadar Nitrat dan Fosfat di Perairan Pesisir Kota Tarakan, Kalimantan Utara. Jurnal Harpodon Borneo, Vo. 8, No.1: 27:34.

Baherem, B., Suprihatin, S., \& Indrasti, N. S. (2014). Strategi Pengelolaan Sungai
Cibanten Provinsi Banten Berdasarkan Analisis Daya Tampung Beban Pencemaran Air dan Kapasitas Asimilasi. Jurnal Pengelolaan Sumber Daya Alam dan Lingkungan, Vol.4, No. 1.

Yustiani, Y. M., \& Komariah, I. (2017). Investigation on the Biodegradation Capacity of Urban Rivers in Jakarta, Indonesia. International Journal of Geomate, Vol.12, Issue 34: 45-50. 